is the reduced life span of erythrocytes coated with antibody, presumably from phagocytosis by reticuloendothelial cells. A further possibility, however, is the relative failure of erythropoiesis or haemopoiesis in general. This might explain the leucopenia and thrombocytopenia in some more severely affected fetuses, with an absence in some of them of reticulocytosis or erythroblastaemia. A megaloblastic crisis, where an arrest of haemopoiesis due to folic acid or vitamin B occurs, is a recognised complication of chronic haemolytic anaemia. ${ }^{20} 21$ Although in theory this could apply to some cases of erythroblastosis, one study showed that administering high doses of vitamin $\mathrm{B}$, folic acid, and other known haematinics to the mother did not noticeably benefit the fetal blood. ${ }^{22}$

Our findings suggest that in the late mid-trimester the rhesus isoimmunised fetus has a large adaptive functional reserve that maintains tissue oxygenation despite severe anaemia. When the haemoglobin concentration is reduced to one third of the normal value, however, tissue hypoxia, indicated by increased erythropoiesis, becomes apparent. Evidence suggests that more severe tissue hypoxia ultimately leads to widespread haemopoietic failure.

\section{References}

1 Nicolaides $\mathrm{KH}$, Rodeck $\mathrm{CH}$. Fetal therapy. In: Studd JWW, ed. Progress in obstetrics and gynaecology. Edinburgh: Churchill Livingstone, $1985: 36-57$. trimester of pregnancy. Br Med f 1978;ii:728-30.
3 Rodeck $\mathrm{CH}$, Campbell S. Umbilical cord insertion as a source of pure fetal blood for prenatal diagnosis. Lancet $1979 ; \mathrm{i}: 1244-5$.

KH. Fetoscopy and fetal tissue sampling. $\mathrm{Br}$ Med Bull Rodeck CH, Holman CA, Karnicki K, Kemp JR, Whitmore DN, Austin MA. Direct intravascular fetal blood transfusion by fetoscopy in severe rhesus

isoimmunisation. Lancet $1981 ; \mathrm{i}: 625-7$.
$6 \mathrm{Rodeck} \mathrm{CH}$, Nicolaides $\mathrm{KH}$. Ultrasound guided invasive procedures in obstetrics. Clin Obstet Gynecol 1983;10:515-39.

7 Liley AW. Liquor amnii analysis in the management of the pregnancy complicated by rhesus sensitisation. Am $\mathcal{F}$ Obstet Gynecol $1961 ; 82: 1359-70$.

Campbell S, Pearce JM. Ultrasound visualisation of congenital malformations. Br Med Bull 1983;39:322-31.

9 Oski FA, Naiman JL. Normal blood values in the newborn period. In: Schaffer A, ed. Hematological problems in the newborn. 2nd ed. Philadelphia: W B Saunders,

10 Playfair JHL, Wolfendale MR, Kay HEM. The leucocytes of peripheral blood in the human fetus. $\mathrm{Br}$ f Haematol $1963 ; 9 \cdot 336-44$

政 of foetal blood. Br $\mathcal{F}$ Haematol 1962;8:290-5.

12 Stohlman FS. Erythropoiesis. N Engl $尹$ Med $1962 ; 267: 342-8$.

13 Kirkinen P, Jouppila P, Eik-Nes S. Umbilical venous flow as an indicator of fetal anaemia. Lancet $1981 ;$ i:1004-5.

14 Griffin D, Cohen-Overbeek T, Campbell S. Fetal and utero-placental blood flow. Clin Obstet Gynecol 1983;10:565-602.

15 Phibbs RM, Johnson P, Tooley $\mathrm{H}$. Cardiorespiratory status of erythroblastic new born infants. II. Blood volume, hematocrit, and serum albumin concentration in relation to hydrops fetalis. Pediatrics $1974 ; 53: 13-23$.

16 Adamsons K. Prophylaxis and treatment of erythroblastosis fetalis. 7 La State

Med Soc 1967;119:465-73.
17 Habibi B, Homberg JC, Schaison G, Salmon C. Autoimmune hemolytic anemia in children: a review of 80 cases. Am $\mathcal{F}$ Med 1974;56:61-9.

18 Hawksley JC, Lightwood R. A contribution to the study of erythroblastosis: cterus gravis neonatorum. $Q \mathcal{F}$ Med $1934 ; 3: 155-209$ with repeated and massive exchange transfusions. Am 7 Clin Pathol 1948; 18:141-51.

20 Chanarin I, Davie JV, Mollin DL. Folic-acid deficiency in haemolytic anaemia. Br f Haematol 1959;5:245-56.

21 Allgood JW, Chaplin $\mathrm{H}$. Idiopathic acquired autoimmune hemolytic anemia. Am $\mathcal{F}$ Med 1967;43:254-73.

22 Allen FH Jr, Diamond LK. Attempts at prevention of intrauterine death in erythroblastosis fetalis. $N$ Engl $\mathcal{F}$ Med $1963 ; 269: 1344-9$.

(Accepted 5 December 1984)

\title{
Hepatitis B virus DNA and e antigen in serum from blood donors in the United Kingdom positive for hepatitis B surface antigen
}

\author{
T J HARRISON， V BAL， E G WHEELER，T J MEACOCK， J F HARRISON， A J ZUCKERMAN
}

\begin{abstract}
Serum samples from 214 blood donors in the United Kingdom who were carriers of hepatitis $B$ surface antigen (HBsAg) were examined for hepatitis $B$ virus deoxyribonucleic acid (DNA) by DNA:DNA hybridisation and for hepatitis $B$ e antigen (HBeAg) and its antibody. One fifth of the donors carried infectious virus in their circulation. The presence of hepatitis $B$ virus DNA correlated well with that of $\mathrm{HBeAg}$, although hepatitis $B$ virus DNA was found in five serum samples that were negative for $\mathrm{HBeAg}$.
\end{abstract}

Wolfson Unit of Molecular Medical Microbiology and Parasitology and Department of Medical Microbiology, London School of Hygiene and Tropical Medicine, London WC1E 7HT

T J HARRISON, BSC, PHD, senior lecturer

V BAL, MD, visiting scientist

A J ZUCKERMAN, MD, FRCP, professor of medical microbiology

North East Thames Regional Blood Transfusion Centre, Brentwood, Essex

E G WHEELER, FIMLS, MIBIoL, chief medical laboratory scientific officer T J MEACOCK, FIMLS, chief medical laboratory scientific officer

J F HARRISON, MRCP, MRCPATH, director

Correspondence to: Dr T J Harrison, Wolfson Unit of Molecular Medical Microbiology and Parasitology.
It is concluded that analysis of serum samples for hepatitis B virus DNA by hybridisation should be the method of choice for determining whether carriers of HBsAg are infectious.

\section{Introduction}

In carriers of hepatitis B surface antigen (HBsAg) viral replication may be continuing in the hepatocytes, with release of infectious virus into the blood stream, or may have stopped, with subsequent clearance of virus from the circulation. Hepatitis B virions may be detected in samples of serum or plasma by assaying for endogenous deoxyribonucleic acid (DNA) polymerase, ${ }^{12}$ although a more direct assay, based on the hybridisation of a cloned hepatitis $B$ virus DNA probe to extracts of such samples, has become the method of choice because of its greater sensitivity and ease of application. ${ }^{3-5}$

The serological presence of hepatitis $\mathrm{B}$ e antigen $(\mathrm{HBeAg})$ is correlated with that of infectious virus, ${ }^{6}{ }^{7}$ and clearance of virus from the circulation often results in seroconversion with the appearance of antibodies to $\mathrm{HBeAg}$ (anti-HBe). ${ }^{8}$ Recent reports, however, have established that an appreciable proportion of patients with anti-HBe have detectable amounts of hepatitis B virus DNA in the serum and so are potentially infectious. ${ }^{9-11}$ We examined serum samples from 214 blood donors, who were positive for $\mathrm{HBsAg}$, for the presence of hepatitis $\mathrm{B}$ virus DNA 
by DNA:DNA hybridisation and for $\mathrm{HBeAg}$ and anti-HBe to determine the prevalence of infectious virus, and to investigate whether the presence of $\mathrm{HBeAg}$ or its antibody correlated with the presence of infectious virus in blood donors in the North East Thames region of Greater London.

\section{Materials and methods}

The 214 serum samples tested were obtained from blood donated to the Regional Blood Transfusion Centre, Brentwood, from February 1974 to December 1982. The presence of HBsAg in each sample was confirmed by solid phase radioimmunoassay (Blood Products Laboratory, Elstree, England). The presence of $\mathrm{HBeAg}$ and its antibody was determined by enzyme linked immunosorbent assay (Organon Technika BV, Boxtel, Holland).

Detection of hepatitis B virus DNA by hybridisation was as described previously ${ }^{4}$ except that a simplified procedure, modified from that of Scotto et al, ${ }^{5}$ was used to prepare the samples for application to the nitrocellulose filter. Serum samples $(50 \mu \mathrm{l})$ were mixed with $20 \mu \mathrm{l} \quad 10 \% \mathrm{NP} 40$ and $20 \mu \mathrm{l} 3 \%$ 2-mercaptoethanol to disrupt any virus present. The samples were then mixed with an equal volume of $2 \mathrm{M}$ sodium chloride and denatured by addition of a double volume of $1 \mathrm{M}$ sodium hydroxide, and 180,90 , and $45 \mu \mathrm{l}$ aliquots were applied to a nitrocellulose filter via a Hybridot manifold (BRL, Paisley, Scotland). Each filter comprised up to 20 test samples, known positive and negative control serum samples, and a reconstruction containing hepatitis B virus DNA that had been cloned in a plasmid (figure). Hybridisation conditions were as described previously ${ }^{4}$; autoradiography was for 24-48 hours followed by extensive re-exposure of one to two weeks.

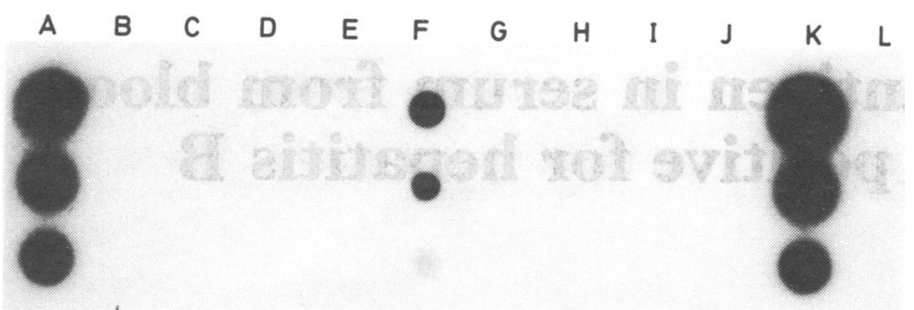

Dot hybridisation assay of serum samples from 10 donors (A-J). Autoradiograph was exposed for 10 days. Sample A was strongly positive for hepatitis $B$ virus DNA and sample F weakly so. The eight other samples were scored negative for hepatitis B virus DNA. Sample K was a reconstruction containing cloned hepatitis B virus DNA (152, 76, and $38 \mathrm{pg}$ plasmid). Sample L was the negative control.

\section{Results}

The table presents data from the analysis of the 214 serum samples for $\mathrm{HBeAg}$ and anti-HBe and for the presence of hepatitis B virus DNA by hybridisation. Most of the samples (160) were positive for anti-HBe; of these, only four were positive for hepatitis B virus DNA. Eight samples that were positive for hepatitis B virus DNA gave a weak

Analysis of serum samples containing $\mathrm{HBs} A g$ for $\mathrm{HBeAg}$, anti-HBe, and hepatitis $B$ virus DNA

\begin{tabular}{lcc} 
& \multicolumn{2}{c}{ Hepatitis B virus DNA } \\
\cline { 2 - 3 } Serological state & Present & Absent \\
\hline HBeAg negative, anti-HBe positive & 4 & 157 \\
HBeAg positive, anti-HBe negative & 39 & 2 \\
HBeAg and HBeAb negative & 1 & 11 \\
\hline Total & 44 & 170 \\
\hline
\end{tabular}

hybridisation signal that could be detected on a two week, but not on a three day, autoradiographic exposure. All five serum samples that were negative for $\mathrm{HBeAg}$ and positive for hepatitis $B$ virus DNA fell into this group.

\section{Discussion}

HBeAg was detected in 42 of $214(20 \%)$ blood donors positive for HBsAg. This finding closely agrees with that of Dow et al, who found that $18.3 \%$ of Scottish blood donors positive for $\mathrm{HBsAg}$ were also positive for $\mathrm{HBeAg} .^{12}$ Our detection of hepatitis $B$ virus DNA in five serum samples that were negative for $\mathrm{HBeAg}$, as well as in all but two of the samples positive for $\mathrm{HBeAg}$, suggests that in this population one fifth of carriers of HBsAg who are otherwise apparently healthy have infectious virus in their circulation.

Our findings showed a good correlation between $\mathrm{HBeAg}$ and anti-HBe state and the presence of infectious virus as detected by DNA:DNA hybridisation in the population of the United Kingdom. This contrasts with findings in southern Europe ${ }^{9} 10$ and Israel, ${ }^{11}$ where up to half of patients with $\mathrm{HBeAb}$ and liver disease may have detectable levels of hepatitis B virus DNA in their serum. Of the five donors who were negative for $\mathrm{HBeAg}$ and positive for hepatitis B virus DNA, one was born in India, one was Chinese, and the remaining three were British.

The detection of hepatitis B virus DNA in five serum samples that were negative for $\mathrm{HBeAg}$, with the implication of the presence of infectious virus, has important consequences in the assessment of risk-for example, in pregnant women who are carriers. We therefore believe that analysis of serum samples for hepatitis $B$ virus DNA by hybridisation should be the method of choice for determining whether a carrier of HBsAg is infectious.

This work was supported by grants from the Wolfson Foundation and the Department of Health and Social Security. Technical help was provided by Mark Bowerman and Hazel Smith. We thank Dr P Valenzuela and Dr W Rutter for their generous gift of the clone of hepatitis $\mathrm{B}$ virus, plasmid pEco 63.

\section{References}

1 Kaplan PM, Greenman RL, Gerin JL, Purcell RH, Robinson WS. DNA polymerase associated with human hepatitis B antigen. $\mathcal{F}$ Virol 1973;12:995-1005. porschman SZ, Gerber M, Garfinkel E. Differential activation of hepatitis B DNA polymerase by detergent and salt. $\mathcal{F}$ Med Virol 1978;2:61-76.

Berninger M, Hammer $M$, Hoyer B, Gerin JL. An assay for the detection of the DNA genome of hepatitis $B$ virus in serum. $\mathcal{F}$ Med Virol 1982;9:57-68. 4 Harrison TJ, Tsiquaye KN, Zuckerman AJ. Assay of HBV DNA in the plasma of Hirol Methods 1983;6:295-302.

5 Scotto J, Hadchouel M, Hery C, Yvart J, Tiollais P, Brechot C. Detection of hepatitis B virus DNA in serum by a simple spot hybridisation technique : comparison with results for other viral markers. Hepatology 1983;3:279-84.

6 Alter HJ, Seeff LB, Kaplan PM, et al. Type B hepatitis: the infectivity of blood positive for $e$ antigen and DNA polymerase after accidental needlestick exposure. N Engl f Med 1976;295:909-13.

7 Howard CR, Zanetti AR, Zuckerman AJ. The nature of hepatitis B e antigen f Med Virol 1978;3:59-66.

8 Craxi A, Weller IVD, Basendine MF, et al. Relationship between HBV-specific DNA polymerase and $\mathrm{HBe}$ antigen/antibody system in chronic $\mathrm{HBV}$ infection factors determining selection of patients and outcome of antiviral therapy. Gut $1983 ; 24: 143-7$.

9 Lieberman HM, La Brecque DR, Kew MC, Hadziyannis SJ, Shafritz DA Detection of hepatitis $B$ virus DNA directly in human serum by a simplified molecular hybridisation test: comparison to $\mathrm{HBeAg} / \mathrm{anti-HBe}$ status in HBsAg carriers. Hepatology $1983 ; 3: 285-91$

10 Hadziyannis SJ, Lieberman HM, Karvountzis GG, Shafritz DA. Analysis of liver disease, nuclear $\mathrm{HBcAg}$, viral replication, and hepatitis $B$ virus DNA in liver and serum of $\mathrm{HBeAg}$ vs anti- $\mathrm{HBe}$ positive carriers of hepatitis $\mathrm{B}$ virus. Hepatology 1983;3:656-62.

11 Tur-Kaspa R, Keshet E, Eliakim M, Shouval D. Detection and characterization of hepatitis $B$ virus DNA in serum of $\mathrm{HBe}$ antigen-genative $\mathrm{HBsAg}$ carriers. f Med Virol 1984;14:17-26.

12 Dow BC Macvarish I Barr A Crawford RJ, Mitchell R. Significance of tests for $\mathrm{HBeAg}$ and anti-HBe in $\mathrm{HBsAg}$ positive blood donors. $\mathcal{F}$ Clin Pathol 1980 ; 33:1106-9.

(Accepted 27 November 1984) 